\title{
ENSEMBLE OF CONSTRUCTIVE TECHNIQUES IN THE CASTLE OF RICOTE (MURCIA, SPAIN)
}

\author{
I. Almela ${ }^{1, *}$, L. Martínez ${ }^{2}$ \\ ${ }^{1}$ PhD student, Escuela de Estudios Árabes, Granada, Spain - inigo.almela@gmail.com \\ ${ }^{2}$ Germany - lucia.martinezbernal@gmail.com
}

Commission II - WG II/8

KEY WORDS: Murcia, Ricote, Castle, Rammed Earth, Constructive Techniques, Building Archaeology

\begin{abstract}
:
The Castle of Ricote, also known as Los Peñascales, is a fortification on a steep hill of the Ricote Valley overlooking the Vega Media of the Segura River, to the east, and the village of Ricote to the west. According to written sources, the history of this castle dates back from the ninth century. However, its military and administrative weight persisted even after the Christian conquest, when it became the headquarters of the Order of Santiago, until the fifteenth century. Despite its poor state of repair, the use of the castle overtime can be established on the site by means of a rather complex sequence of phases and a very heterogeneous set of construction techniques. Although it has been hard to accomplish a complete analysis, in this paper we have attempted a stratigraphic analysis and a synthesis of the techniques used in the medieval interventions, which are highly relevant due to their diversity and special features. Among them, the following have been covered: stonework with lime mortar built through shuttering, rammed earth, and lime-crusted rammed earth. In addition, the two main phases detected, and their respective techniques will also be underlined, since they are present consistently throughout the whole castle.
\end{abstract}

\section{INTRODUCTION}

To this day, the Castle of Ricote has barely been researched, except for specific works that just dealt with it superficially. This paper starts with a brief geographical and historical context of the castle, based on the scarce bibliography that exists.

Next, we offer a general description, trying to avoid complex interpretations, but seeking the most organized and unified way of approaching such a deteriorated castle, whose remains are completely disjointed.

Lastly, we present the most relevant part of this work, that consists of a classification and description of the different types of construction techniques identified. In addition, where possible, we try to highlight the potential stratigraphic connections between the units built using different techniques, in order to carry out a chronotypological classification.

\section{METHODOLOGY}

The work that we carried out was based on a first survey that comprises different aspects, such as the drawing of a draft general plan of the castle (Figure 1), the documentation of visible and well preserved structures, the collection of data for photogrammetry and planimetry, the archaeological analysis, and the elaboration of stratigraphic recording sheets for each stratigraphic unit.

Unfortunately, the technical challenges presented by this castle have prevented us from completing an exhaustive archaeological analysis. Nevertheless, due to the relevance of the set of construction techniques, we decided to attempt to classify them (Figure 2).

\section{EL CASTILLO DE RICOTE}

\subsection{The Ricote Valley}

The Ricote Valley is a natural area with high scenic value located in the Vega Alta del Segura, in the north of the region of Murcia. It is a natural county structured around the Segura River, which flows from northwest to southeast between rugged and barren mountains. All these elements conditioned the creation of settlements connected to agricultural irrigation systems in the narrow banks (Bazzana et al., 1997). The valley is currently made up of the municipalities of Cieza, Abarán, Banca, Ojós, Ulea, Villanueva del Río Segura, Archena, and Ricote, although the latter is the only one not located right next to the river. The village of Ricote lies on a small plain to the west of the river course, surrounded by mountains and connected to the valley by means of a natural pass where the ravines and ditches flow into the river.

This plain is completely occupied by a collective orchard of Andalusian-Medieval origin, whose water supply comes from some springs (Puy, 2012). On the north limit, at the foot of the Algezar hill, lies the inhabited village of Ricote. The name of this hill refers to the gypsum composition of the soil in the area. Next, the castle stands on a much higher mount overlooking both the orchards to the West and the valley to the East.

\subsection{Historical Context}

Based on written material, the castle already existed in the 9th century, however due to its military and administrative weight, it remained in use even after the Christian conquest, when it became the headquarters of the Order of Santiago (until the 15 th century).

* Corresponding author 
The castle played an important role throughout the Middle Ages, as it was a point of military control and the socioadministrative hub for the population of Ricote. This aspect explains its continued use, and probably its expansion, reform, and refurbishment at different points in time. Thus, the building that made it to our days presents a sequence of phases and an important repertoire of architectural and constructive solutions.

So far, the most important work on the castle is the one written by Professor J. A. Eiroa (2008), a study in which he gathered several fragments of medieval written sources. This study established the identification of the site with the one mentioned in sources as Ḥiṣn Riqūṭ, Hiṣn al-Ṣujūr or al-Șujayrat. The oldest reference appears in the chronicle by Ibn Hayyān, who narrates the military campaign of the Umayyad Emirate in the year 896 to the southeast of al-Andalus against the Lorca rebel Daysam ibn Ishāq. This source mentions the existence of a "first wall belt" and an "alcazaba" (Eiroa, 2008, p. 9).

According to other 10th and 11th century texts, on this enclave there was a fortress (hiṣn) called al-Șujūr and a village (alqueria) called Riqūt, although al-Idrīsī in the 12th century offered again a mixed denomination of the place as Hișn Riqūt (Eiroa, 2008, p.10). In the 13th century, the castle reappears under the name Hiṣn al-Ṣujūr or Hiṣn al-Ṣujayrāt, mentioned as it was the place where Ibn Hūd rose against the Almohads. However, other authors have placed these locations on other parts of the valley, such as the Salto de la Novia (López, 2008, p. 29-33).

After the Castilian conquest, the valley fell under the control of the Order of Santiago, and the Castle of Ricote became its main headquarters since 1285 . The Order's 15th-century documents are very detailed (Eiroa, 2008, p. 10-12).

\subsection{Overview of the Remains}

The Castle of Ricote covers an approximate area of 0.5 hectares and stands approximately 405 meters above sea level on a hill that is part of the Sierra del Salitre, overlooking the Vega Media of the Segura River and the Ricote plain. It was listed as Asset of Cultural Interest (BIC) in 1985, although this recognition has not led to any conservation measures or an archaeological survey.

Based on the Santiago documents and the material remains, Eiroa suggested that the castle consisted of two areas. On the one hand, the albacar, a large enclosure protected by a towered wall that adapts to the topography. Inside this area, there are remains of structures, and the main access on the eastern flank. On the other hand, the area referred to as celloquia comprises several structures and warehouses perched on the top of the hill (Eiroa, 2008, p. 11-12).

The terrible state of repair of the castle and its high level of deterioration greatly hinder its spatial interpretation. Normally, walls allow us to establish the perimeter of the enclosures, but in this case many parts have disappeared, some are half buried, and others may have never existed due to the natural steep hill that made it unnecessary to build a fence.

Despite this, based on the observations that we were able to make of the ensemble, both enclosures follow the same display (Figure 1).
On the upper area, the northwest sector of the castle features an approximately triangular enclosure perched on the north cliff, while on the south it is surrounded by an intermittent sequence of walls and towers. Numerous structures are concentrated in this sector, which are staggered and connect to each other through stairs due to the steep terrain. Some of them stand out such as the upper tower (A) located on the highest area and accessible only by stairs carved on the rock, the lower "building" (B), the corner of a possible tower (C), Tower D and the spur-tower (E). To the east of Tower A there is a cistern. It may appear to be outside the area of the castle, but we believe that it was part of the upper enclosure, as it was protected by Spur-tower E.

The lower enclosure, whose function could effectively be that of an albacar, extends to the southwest of the upper enclosure and adapts to the usable area of the hilltop, restricted by steep slopes. Its layout presents at least four towers, three in the western area (F, G, and $\mathrm{H}$ ) and another one of greater dimensions (I) in the southeast corner, which serves as connection with the eastern wall of the enclosure. This last tower, one of the best preserved, has a trapezoidal plan and features several reinforcements. Its eastern front is the most solid one, since it was covered by the end of the eastern wall (Figures 3 and 4). The main gate stands next to this tower (J). It is structured as a bend between two walls. The foundations and one of the jambs of the access are still in place (Figure 5). Attached to the inner side of this wall there is a collapsed cistern.

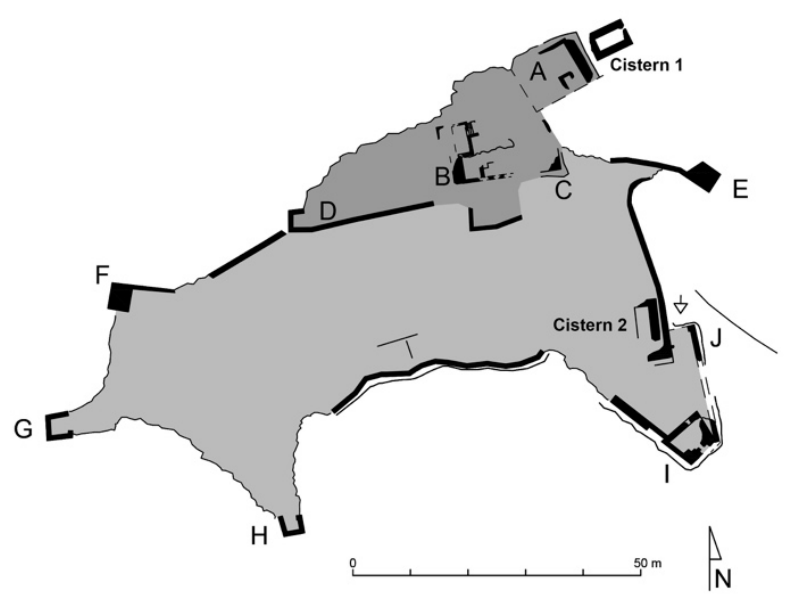

Figure 1. Layout drawing of the castle.

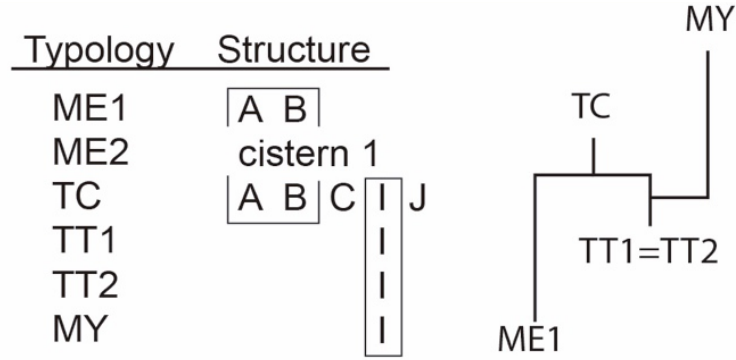

Figure 2. Table of typologies-structures and typology matrix. 


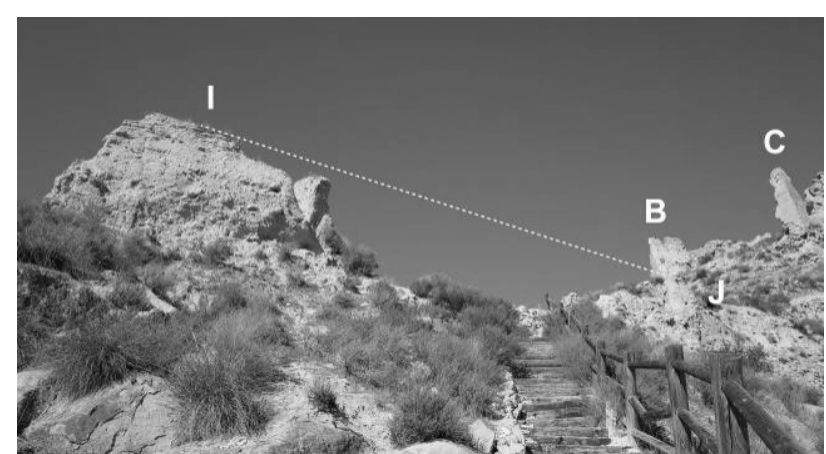

Figure 3. View of the east elevation of the castle.

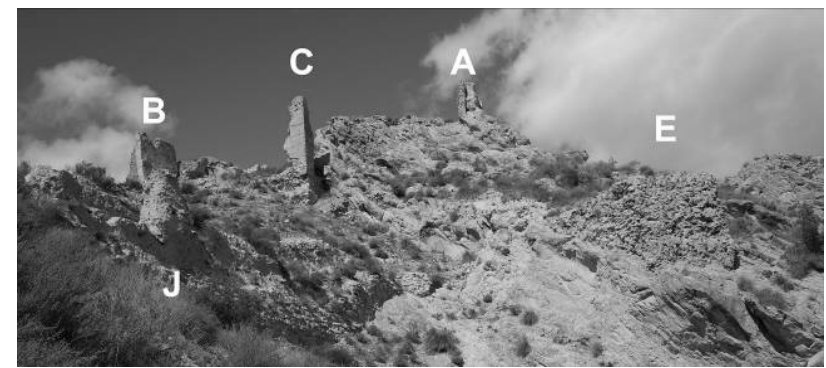

Figure 4. View of the east elevation and the upper enclosure.

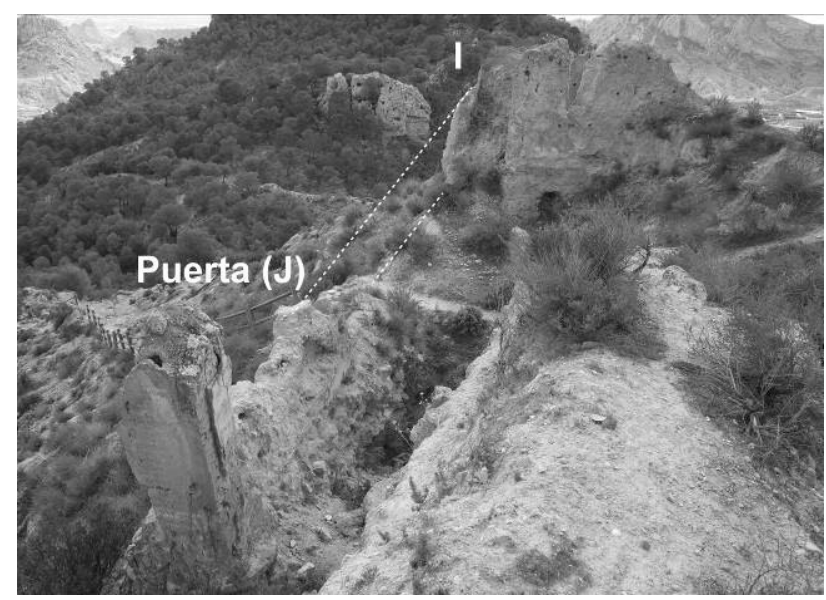

Figure 5. View of the ensemble composed of Tower I and Gate J.

\section{CONSTRUCTIVE TECHNIQUES}

As consequence of the lack of a comprehensive understanding of all the structures and the absence of an exhaustive stratigraphic analysis, it was not possible to establish a phase sequence that would allow us to explain the complete evolution of the castle. However, a partial analysis of each structure made it possible to identify a set of stratigraphic units and their relations, since each unit features a specific construction technique (Figure 2).

Given the constructive and technical similarity between the different units located in different structures of the castle, and the relative parallelism in their stratigraphic sequence, it was decided to classify them as constructive techniques that follow a typological aim.

\subsection{Lime Mortar-Stonework with Shuttering 1 (ME1)}

This technique is well documented in the intermediate Tower $\mathrm{B}$ and high Tower A. In both cases it is directly related to a later phase that involved the reinforcement of lime-crusted rammed earth (CT). This material is attached externally to (ME1) in both cases.

The west elevation of Tower B is largely preserved and comprises a wall built using this technique. It is $0.53 \mathrm{~m}$ wide and consists of shuttering work of medium and large stones (limestone, dolomite and marl) agglomerated with lime mortar (Figures 6 and 7). The stones are not set in regular courses. The mass includes pieces of tile and pottery. The boxes are $0.82 \mathrm{~m}$ high and they present putlog holes sealed with the same mortar as the mass. In the corner, it is possible to see how the boxes are interlocked between the two walls (Figures 8 and 9). There is an outer layer of gypsum plastering.

Tower A also preserves its large east-facing front and part of its north side, which form a solid corner together (Figure 10). The imprint of the barzón (wood strip of the shuttering) near the outer corner is very interesting. The outer face of the eastern front is almost perfectly preserved behind a reinforcement wall of lime-crusted rammed earth (TC) (Figure 11). However, the northern front of Tower $A$ was not externally reinforced similarly, and therefore its outer face is quite damaged.

Both Building B and Tower A present thin walls built with this technique, so it is not surprising to find that in both cases they have been refurbished with an external coating. This relation is evidenced by observing how this lining was attached to the plastering of (ME1) (Figures 8 and 9). This means that this technique could be one of the oldest recorded in the castle.

\subsection{Lime Mortar-Stonework with Shuttering 2 (ME2)}

This technique was recorded in the construction of the upper cistern, although due to its characteristics and being an hydraulic structure, we decided to consider it as a different technique. Much of the cistern structure has survived, except the vault and one of its short sides, which have collapsed.

In this case, the stones were set in well-defined and regular courses, which were set with a lime mortar rich in gravel. In addition, it seems that the interior faces of the walls were executed with a greater proportion of mortar and small stones, while in the exterior ones, larger pieces and less proportion of mortar were used (Figure 12).

\subsection{Lime-Crusted Rammed Earth (TC)}

As already advanced in Section 4.1, this technique was the one used for lining ME1 in Tower A and Building B. However, it is also recorded in other points, such as Tower $\mathrm{C}$, the eastern wall of Tower I and the gate (J).

In towers $\mathrm{A}$ and $\mathrm{B}$, where it has been possible to observe this technique correctly, it is up to $1.44 \mathrm{~m}$ wide, and the composition is very earthy, with much waste (pottery and bones) included. There is a smaller ratio of stones, that are different sizes. Likewise, gravel predominates (Figure 9). 


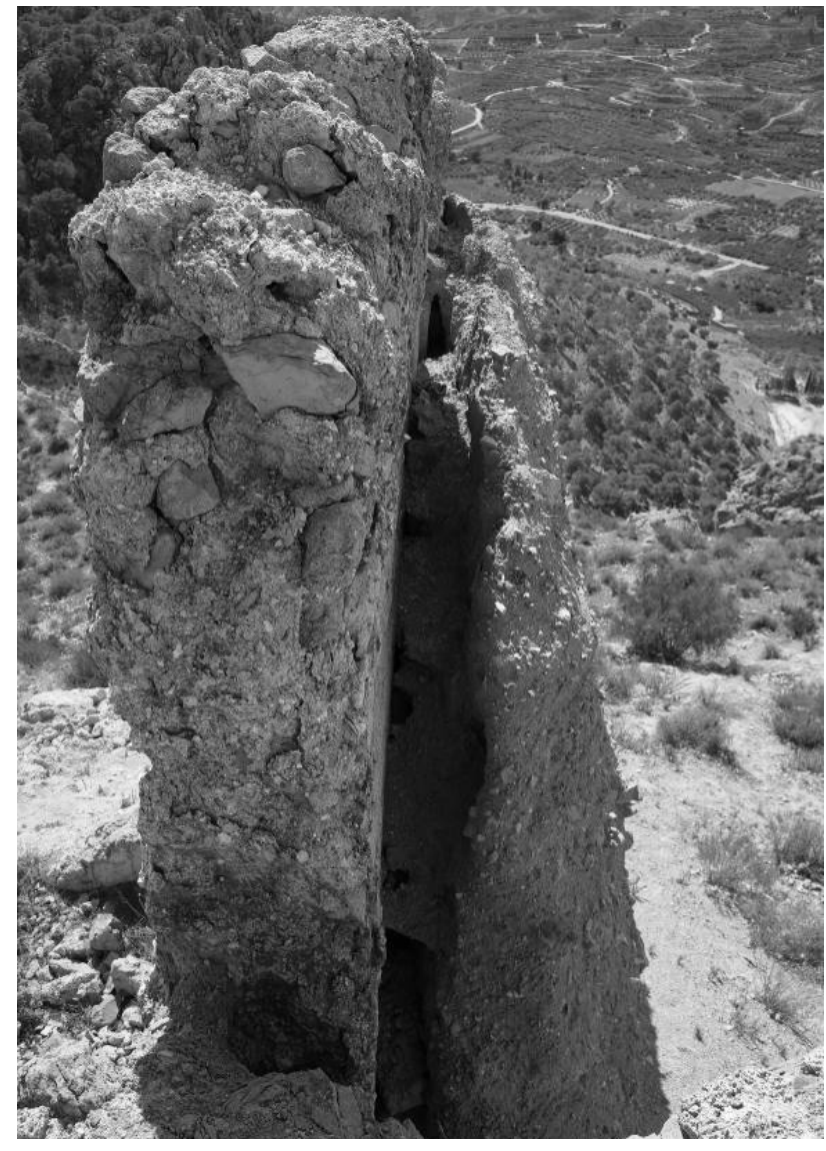

Figure 6. Tower B. Top view of (TC) attached to (ME1).

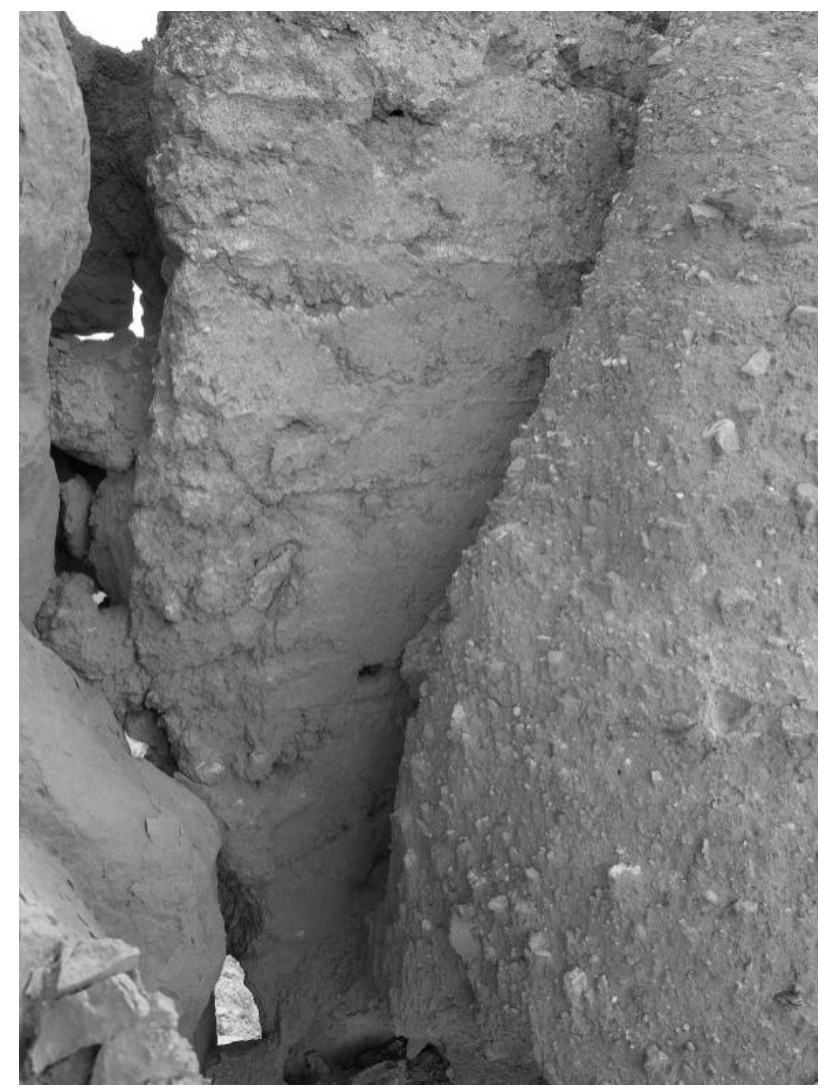

Figure 7. Tower B. (TC) attached to the outer face of (ME1).
In both $\mathrm{A}$ and $\mathrm{B}$, the boxes are $0.79 \mathrm{~m}$ high and have rectangular putlog holes. It is possible to notice the casting sections on the wall faces, although for recognizing the limecrusted technique in more detail it is necessary to observe the lower part, where the wedges and lime mortar beds are more clear (Figure 8). The difference between both materials (earth and lime mortar), has surely prevented the correct adhesion of the layers, causing the detachment of the lime crust.

In the lower part of B there is a cylindrical horizontal hole inside the wall. This seems to correspond to a possible log introduced in the mass of the wall for improving the resistance of the wall against traction (Figure 8). As for putlog holes, some of them still present remains from logs due to the considerable thickness of the wall. In Tower A, the (TC) was built on a slope masonry base (Figures 10 and 11).

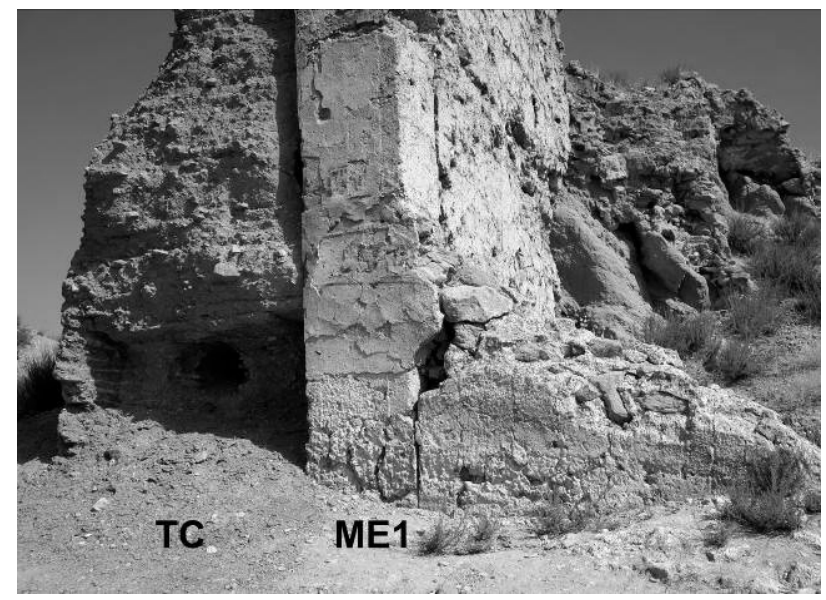

Figure 8. Tower B. Southern front. Connection between (ME1 - TC).

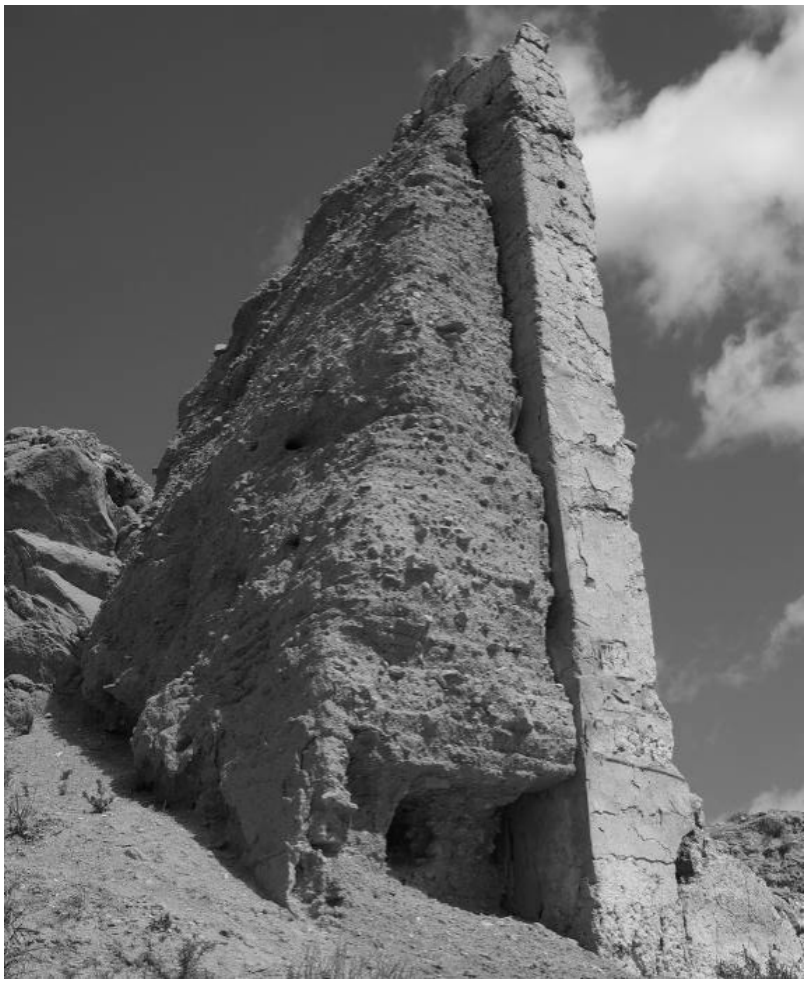

Figure 9. Tower B. (TC) attached to (ME1). 
As for Tower I, the (TC) surrounds the southern and western fronts. It lies on a masonry base and is covering an older rammed earth wall (TT2), as shown by the burrs on the inner corner (Figure 13). This wall is part of the eastern wall that begins at the main gate $(\mathrm{J})$ and surrounds Tower $\mathrm{I}$, although the middle section was lost and the area is used as current access to the castle (Figures 3 and 5). Likewise, the same technique is found on the recessed wall that stretches from the gate to the north, although it is very deteriorated.

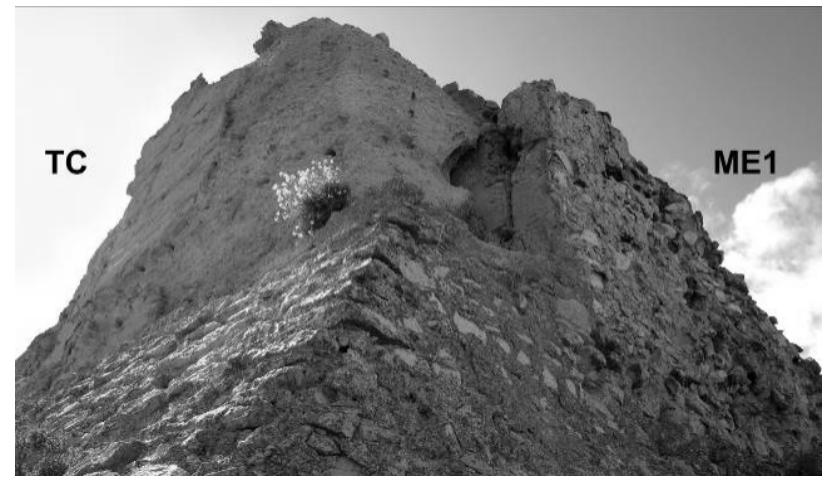

Figure 10. Tower A. North-eastern angle.

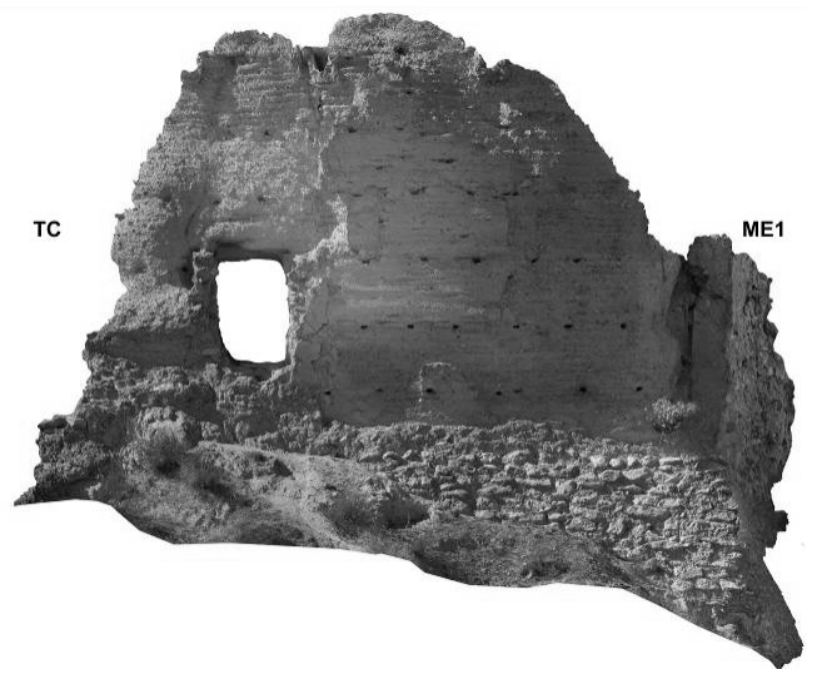

Figure 11. Tower A. Eastern front. Orthomosaic.

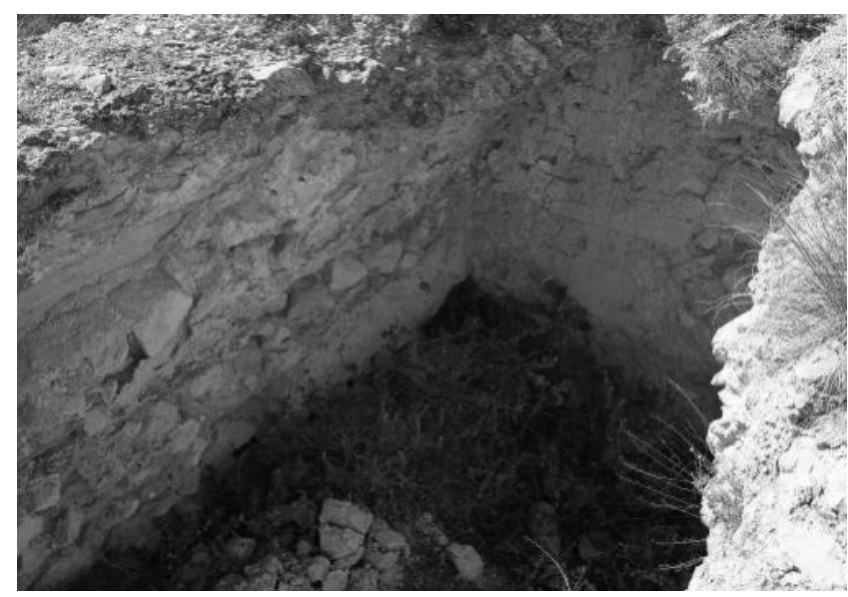

Figure 12. Upper cistern by Tower A.

\subsection{Rammed Earth 1 (TT1)}

The northern front of Tower I was built using the technique of rammed earth, whose composition possibly includes a very low proportion of a binder, such as lime or gypsum (both materials were abundant in the area), boulders, small stones, and gravel, and features small quantities of waste (brick, ceramics, and bones). This wall is $0.98 \mathrm{~m}$ thick. The mixture used has favored the cohesion and conservation of both faces, which also seem to present a crust (Figure 14). The boxes are $0.85 \mathrm{~m}$ high and were built with circular putlog holes, unlike those found on (TC). Outside the tower, it is possible to notice how the wall was built on top of a previous construction, which was evened with rows of small stones and bricks that served as support for the first putlog holes of the new work (TT1).

\subsection{Rammed Earth 2 (TT2)}

Tower I features another different technique on its southern and western fronts, where remains of previous work reinforced by (TC) can be found (Figure 13). It consists of a very light earthy wall, possibly mixed with lime or gypsum like the previous technique (TT1). Its mass includes small stones of variable size and the presence of waste (ceramic and bones).

This unit is in an advanced state of deterioration, which makes it impossible to analyze it, since it has not been possible to observe putlog holes or box dimensions. Its thickness is also difficult to determine, although it probable ranges between 0.60 and $0.87 \mathrm{~m}$. We suspect that (TT2) is equivalent to (TT1), although we lack the data to assert it.

It seems that this technique is also present in other points of the castle, such as the southern wall between towers $\mathrm{H}$ and I, where a much deteriorated fragment appears over a stonework wall (Figure 15).

\subsection{Stonework with Gypsum Mortar (MY)}

This technique is present inside Tower I and in some scattered structures that emerge from the upper enclosure. The remains preserved in Tower I consist of large L-shaped buttresses that reinforce two inner corners of the tower. These are very rough, with different sized stones, not set in regular rows and with gypsum mortar.

\subsection{Other Stonework}

Masonry work is widely present throughout the castle. In most cases, it appears as foundations of rammed earth walls. This is why the existence and trajectory of the missing walls can be proved through the masonry works that survived to our day (Figure 15). Their features are diverse - rows found are regular as well as irregular, stones vary in type and size, and different types of mortar were used.

\section{CONCLUSIONS}

Among the seven constructive techniques catalogued in this paper, two of them stand out because of their typology and their stratigraphic relations within different structures of the castle.

The first one, (ME1) is quite remarkable as it is the typology used in the oldest units. Its masonry and materials reflect a longlasting intention, which contrasts with its narrowness. This last aspect gives these walls little mechanical stability in the case of high-rise walls, like Building B (Figure 9). 
We have not identified yet any examples similar to this technique in other castles and medieval buildings in the area, which could be of great help to establish an approximate chronology. One of the challenges of this technique is how difficult it is to recognize it in the most devastated cases, as the remains could be interpreted as simple stonework or even foundations.

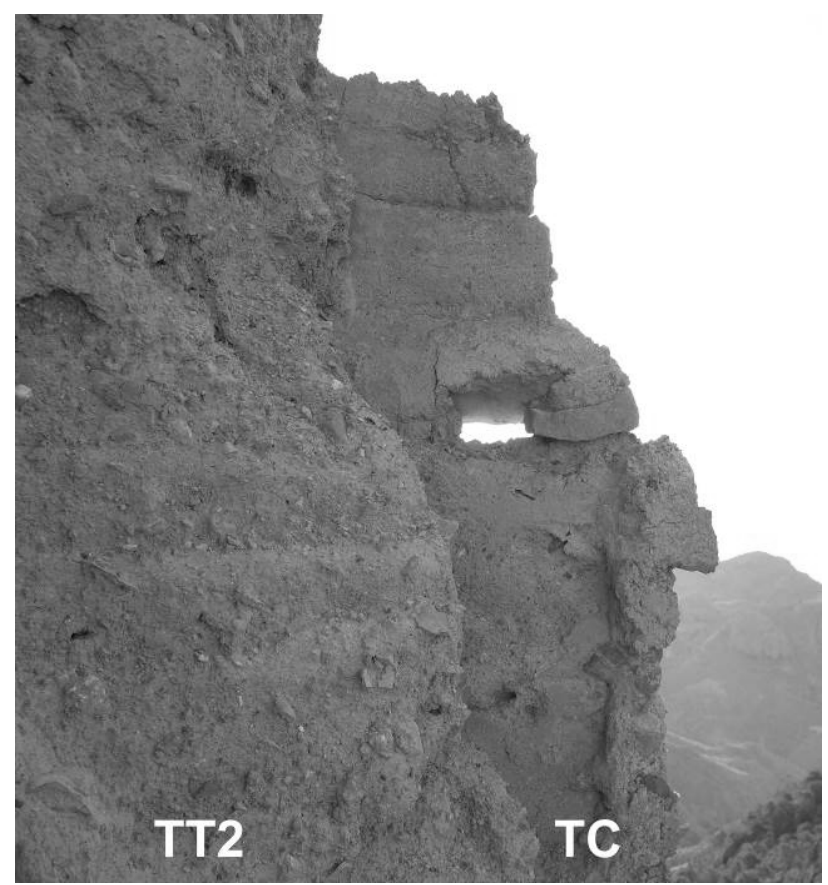

Figure 13. Tower I. Angle of (TT2) and (TC).

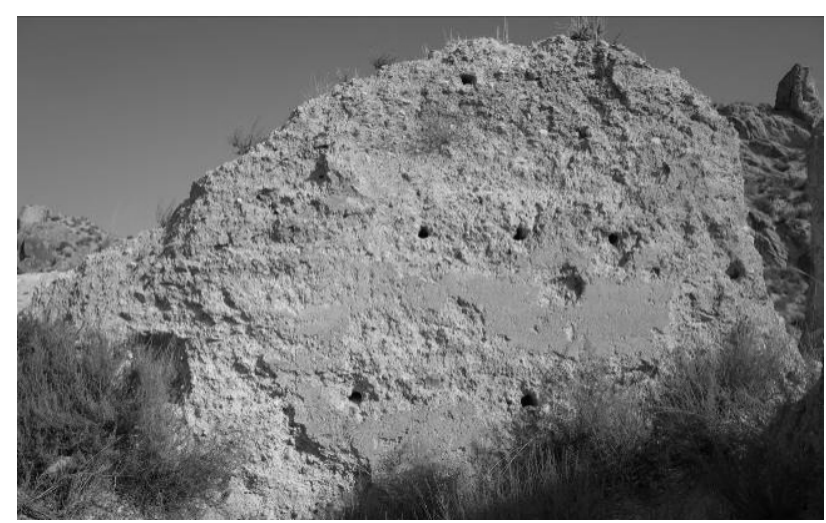

Figure 14. Tower I. Northern front built with (TT1).

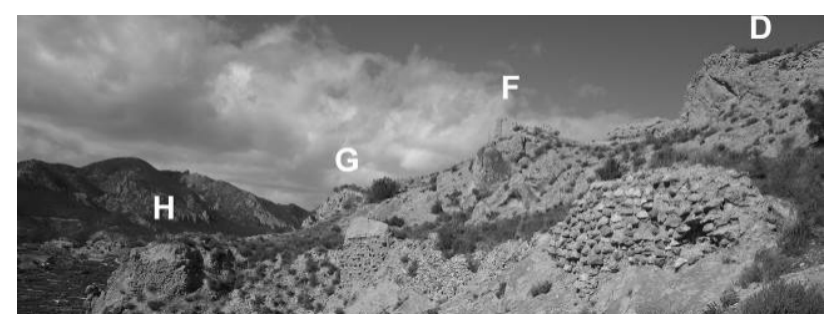

Figure 15. View of the lower enclosure from Tower I.
The second one (TC), is present in many sections and seems to correspond to an integral reform of the castle, which not only reinforced pre-existing structures (towers A, B and I) but also seems to have covered the construction of the eastern wall front of the lower enclosure and bend Gate J. Based on the current knowledge of the matter, the use of this technique may have begun in al-Andalus in the 12th century, peaking during the Almohad period and especially during the Nasrid period (Canivell, Graciani, 2015, p.14). With regard to the particular characteristics of this technique in the Castle of Ricote, we highlight the contrast between the earthy casting sections and the lime crust, which also appears at Castillejo de Monteagudo (Murcia), a building supposedly built by Ibn Mardanīš between 1147 and 1171.

As for the rammed earth walls, they also correspond to units prior to (TC) (lime-crusted rammed earth). Although we do not have enough data to determine their dating with respect to (ME1) (lime mortar-stonework with shuttering), we prefer to consider the rammed earth walls as a possible intermediate phase between them. This is due to the absence of (ME1) in the Late Medieval constructions in the area and the technical similarities of (TT1) and (TT2) with (TC).

Finally, it should be remarked that the Castle of Ricote is an example of how earthen medieval heritage presents an ephemeral and severely perishable character. Its advanced state of degradation is very worrying, and the analysis of its remains gets increasingly complicated. For this reason, it is of paramount importance to document the whole set of construction techniques in the castle, some of which are very interesting for the study of medieval material culture.

\section{REFERENCES}

Bazzana, A., De Meulemeester, J., Matthys, A., 1997. Quelques aspects du peuplement médiéval du Valle de Ricote (Murcie, Espagne), in Rural Settlements in Medieval Europe Papers of the "Medieval Europe Brugge 1997" Conference Vol.6 I.A.P. Rapporten 6. Zellik, 39-54.

Canivell, J., Graciani, A., 2015. Caracterización constructiva de las fábricas de tapia en las fortificaciones almohades del antiguo Reino de Sevilla, Arqueología de la Arquitectura 12: $\mathrm{e} 025$.

Eiroa, J. A., 2008. El castillo de Ricote (Murcia): Identificación y bases para su estudio, in Estudios sobre desarrollo regional. Universidad de Murcia, 7-24.

López, J. J., 2008. El Valle de Ricote a través de sus fortalezas. Rutas históricas por si poblamiento antiguo y medieval. Madrid.

Manzano, J.A., 2002, Arquitectura defensiva: delimitación de entornos y documentación histórica de 20 torres y castillo, Memoria de Arqueología (1995) 10, Murcia, 657-747.

Puy, A., 2012. Criterios de construcción de las huertas andalusies el caso de Ricote (Murcia, España), tesis doctoral Universidad Autónoma de Barcelona. 